\title{
Unusual cause of mediastinal widening
}

\author{
Nishant Jindal 지 , Charanpreet Singh, Pankaj Malhotra
}

Internal Medicine, Post Graduate Institute of Medical Education and Research, Chandigarh, India

\section{Correspondence to Dr Pankaj Malhotra;} hematpgi@gmail.com

Accepted 27 May 2020

\section{DESCRIPTION}

A 63-year-old woman presented to a local centre after an episode of transient chest pain. A chest X-ray revealed mediastinal widening with well-rounded margins (figure 1). A contrast-enhanced CT was done which showed multiple paravertebral masses (figure 2). She was subsequently seen in Pulmonology clinic where a guided fine-needle aspiration cytology revealed extramedullary haematopoiesis and she was referred to the Haematology clinic.

On reviewing the history, she gave history of chronic fatigue and had been transfused 2 units of packed red blood cells (PRBCs) during childbirth. She also complained of on-and-off jaundice which had never been evaluated. Examination revealed mild pallor, icterus and spleen was palpable $6 \mathrm{~cm}$ below the left costal margin. Complete hemogram revealed isolated anaemia (haemoglobin $7.5 \mathrm{~g} / \mathrm{dL}$ ) with microcytosis (mean corpuscular volume 61 $\mathrm{fL})$. Reticulocyte count was $15 \%$ with a reticulocyte production index of 4 . Peripheral blood smear was suggestive of moderate anisopoikilocytosis and showed multiple teardrop cells, elliptocytes and occasional polychromatophils. The presentation and basic investigations were consistent with a chronic haemolytic anaemia with microcytosis, thalassemia being the most obvious differential. High-performance liquid chromatography ( $\mathrm{HbA} 0$ $34.4 \%$, $\mathrm{HbA} 2$ 7.8\% and $\mathrm{HbF} 49.4 \%$ ) confirmed the diagnosis of non-transfusion-dependent thalassemia. She was started on hydroxyurea at $10 \mathrm{mg} /$ $\mathrm{kg} /$ day and administered 2 PRBC transfusions. At 6 months of follow-up, her haemoglobin had risen to $8.6 \mathrm{~g} / \mathrm{dL}$ with marked improvement in fatigue.

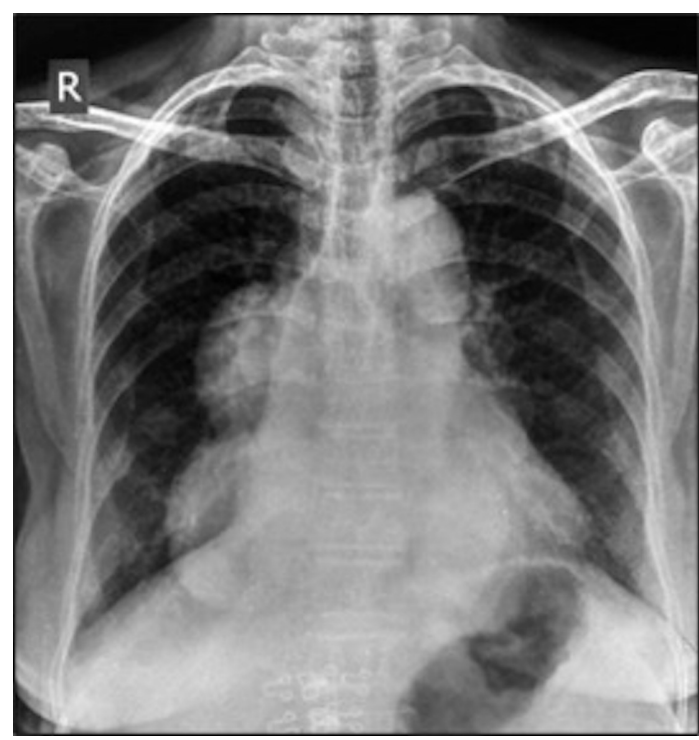

Figure 1 Chest X-ray showing presence of mediastinal widening.

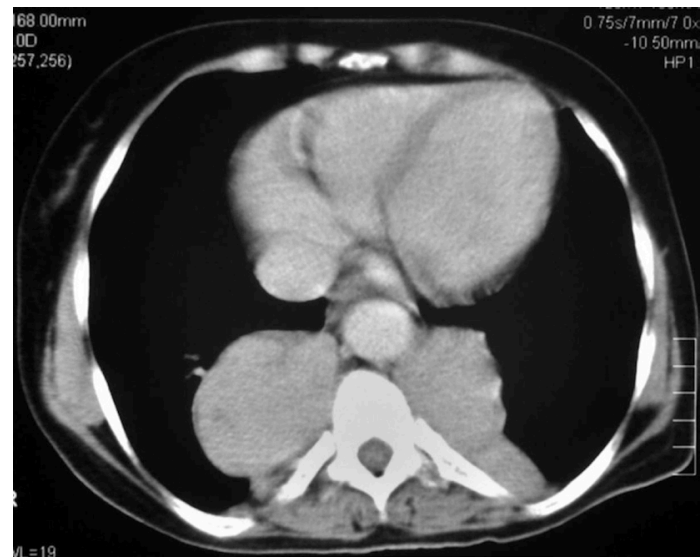

Figure 2 Contrast-enhanced CT chest showing rounded, well-defined paravertebral masses.

Mediastinal widening on chest X-ray is not an uncommon finding. In patients more than 60 years, bronchogenic carcinoma and lymphoma are the most important differentials. Paravertebral extramedullary haematopoiesis as a first manifestation of non-transfusion-dependent thalassemia presenting at this age is exceedingly rare. ${ }^{1}$ Similar 'mediastinal tumours' have been described with other chronic haemolytic anaemias as well. ${ }^{2}$ Well-rounded margins, lumpy nodular opacities and obliteration of cardiac shadow are subtle points that can help differentiate paravertebral extramedullary haematopoiesis from the more common superior mediastinal tumours.

Extramedullary haematopoiesis in patients with thalassemia intermedia occurs as a consequence of ineffective erythropoiesis. It may occur at various sites, including lung, spinal cord, heart and pleura, and may present with a pseudotumour or a mass. A higher rate of extramedullary haematopoiesis has been reported in older patients with thalassemia intermedia. ${ }^{3}$ Management includes regular transfusions and therapies directed at increasing the fetal haemoglobin levels. Local radiation may be considered, especially in those with paraspinal masses causing spinal cord compression. ${ }^{4}$

Learning points

- Paravertebral extramedullary haematopoiesis can be a presenting manifestation of nontransfusion-dependent thalassemia.

- A detailed clinical history and complete physical examination along with subtle radiological differences can help differentiate it from the more common malignant causes of mediastinal widening. 
Images in...

Contributors NJ and CS wrote the paper. PM conceptualised the paper and edited it.

Funding The authors have not declared a specific grant for this research from any funding agency in the public, commercial or not-for-profit sectors.

Competing interests None declared.

Patient consent for publication Obtained.

Provenance and peer review Not commissioned; externally peer reviewed.

\section{ORCID iD}

Nishant Jindal http://orcid.org/0000-0002-1423-1163

\section{REFERENCES}

1 An J, Weng Y, He J, et al. Intrathoracic extramedullary hematopoiesis presenting as tumor-simulating lesions of the mediastinum in $\alpha$-thalassemia: a case report. Oncol Lett 2015;10:1993-6.

2 Park JB, Lee SA, Kim YH, et al. Extramedullary hematopoiesis mimicking mediastinal tumor in a patient with hereditary spherocytosis: case report. Int I Surg Case Rep 2017:41:223-5.

3 Taher AT, Musallam KM, El-Beshlawy A, et al. Age-related complications in treatmentnaive patients with thalassaemia intermedia. Br J Haematol 2010;150:486-9.

4 Musallam KM, Taher AT, Rachmilewitz EA. $\beta$-Thalassemia intermedia: a clinical perspective. Cold Spring Harb Perspect Med 2012;2:a013482.

Copyright 2020 BMJ Publishing Group. All rights reserved. For permission to reuse any of this content visit

https://www.bmj.com/company/products-services/rights-and-licensing/permissions/

BMJ Case Report Fellows may re-use this article for personal use and teaching without any further permission.

Become a Fellow of BMJ Case Reports today and you can

- Submit as many cases as you like

- Enjoy fast sympathetic peer review and rapid publication of accepted articles

- Access all the published articles

Re-use any of the published material for personal use and teaching without further permission

\section{Customer Service}

If you have any further queries about your subscription, please contact our customer services team on +44 (0) 2071111105 or via email at support@bmj.com.

Visit casereports.bmj.com for more articles like this and to become a Fellow 